\title{
Policy, performativity and partnership: an ethical leadership perspective
}

\author{
Geoffrey Elliott ${ }^{1}$ \\ Unmiversity of Worcester
}

Worcester WR2 6AJ

UK

\begin{abstract}
This article identifies the need to think differently about educational partnerships in a changing and turbulent post compulsory policy environment in England. The policy and institutional contexts in which universities and colleges currently operate seem to be fuelling performativity at the expense of educational values. There appears to be a sharp interruption in the steady increase in educational partnerships as a vehicle for increasing and widening participation in higher education. We are witnessing a marked change in university / college relationships that appears to be a consequence of government calling a halt to increased participation in higher education, creating an increasingly competitive market for a more limited pool of student places. The implication that educational policy at the national level determines a particular pattern or mode of leadership decision making throughout an institution should however be resisted. Policy developments that challenge the moral precepts of education should not be allowed to determine how a leader acts, rather they should prompt actions that are truly educational, rooted in morality, and atached to identifiable educational values. Educational leaders have agency to resist restricted discourses in favour of ethical and principled change strategies that are a precondition for sustainable transformative partnerships in post compulsory education. University leaders in particular are called upon to use their considerable influence to resist narrow policy or managerial instrumentalism or performativity and embrace alternatives that are both educationally worthwhile and can enhance institutional resilience.
\end{abstract}

\section{Key words}

Partnerships, leadership, higher education, further education

\footnotetext{
${ }^{1}$ Email: g.elliott@worc.ac.uk
} 


\section{Introduction - The problem in its political context}

This article identifies the need to think differently about educational partnerships in a changing and turbulent post compulsory policy environment in England. Its writing has been prompted by the interruption that seems to be happening to the steady increase of university partnerships with further education colleges as a vehicle for increasing and widening participation in higher education. Its aim is to provide a 'basis for transformative practices, which could serve to question existing structural relationships, and interrupt the economic and reductionist logic that drives the competitiveness agenda' (Avis and Bathmaker 2004, 304).

Parry et al (2012, 93-4) identify four major strategic drivers for universities establishing relationships with further education colleges: legacy (historical links, overlapping provision especially sub-degree), footprint (territoriality, establishing a regional presence, expansion of the civic university), widening participation (through validation arrangements and progression agreements), employer engagement (vocational courses, flexible delivery). The prevalence of the many university college partnerships in England owes much to the benign policy environment that has fuelled each of these major strategic drivers - partnerships as a key additional student number bid requirement, ring-fenced HEFCE funding geared towards HE/FE partnerships (Partnerships for Progression, Lifelong Learning Networks, Aim Higher), FECs seen as central to regional coverage of HE provision and to widening participation especially onto vocational courses, and government policy priority given to improving higher level skills needs.

Increasing and widening participation are central to each of the above drivers and have been highly strategic activities for successive governments and for universities and colleges that have been able to grow through successful joint bids for additional student numbers.

Collaboration in post compulsory education has become a mantra of government and of many educational institutions as they are exhorted to do more within available resources. However, given that many colleges, especially larger ones, themselves vie with universities to attract undergraduate students within a zero sum recruitment game, competition and collaboration sometimes sit uncomfortably together. As higher education numbers become more tightly controlled by government, recruitment to target has become the number one priority for both universities and colleges. In as far as their educational partnerships support this aim, universities have been prepared to maintain them. It is easy to see how the challenging policy and institutional contexts in which universities and colleges operate seem to be fuelling performativity at the expense of educational values, in a reconfiguration of professionalism that has swept across public management, in which performance management, audit and workplace reform are key features, driven by market competition and public choice (Gleeson and James 2007).

Performativity is defined by Ball $(2003,216)$ as: 
a technology, a culture and a mode of regulation that employs judgements, comparisons and displays as means of incentive, control, attrition and change based on rewards and sanctions (both material and symbolic). The performances (of individual subjects or organizations) serve as measures of productivity or output, or displays of 'quality', or 'moments' of promotion or inspection. As such they stand for, encapsulate or represent the worth, quality or value of an individual or organization within a field of judgement.

Partnerships set within a discourse of performativity can be viewed as transactional, representing an exchange of interests that assist towards achieving externally framed criteria and requirements. In the context of the present discussion, the exchange of interests in question is growth in higher education student numbers and the funding associated with these. What we are now seeing is that when these external drivers change the partnerships become vulnerable and in many cases are disbanded.

\section{Increasing participation}

Collaboration between universities and further education has been a prominent feature of the growth in participation to a mass system of higher education (Trow 1974). But there is a second agenda for higher education in further education colleges also supported by government policy (BIS 2009, 104), the provision of vocational HE programmes. As Wood (2012) has noted, the practical complexity of combining FE specialisation on vocational programmes with political and financial encouragement for FE colleges to include larger proportions of underrepresented groups than HE institutions will tend to produce an increasingly complicated pattern of provision. Additional layers of complexity are being introduced as government policy introducing student number controls push some universities to opening subsidiary institutions sometimes in collaboration with further education partners (Morgan 2012). And as Parry (2008, 23) has noted, 'although collaboration between the two sectors has a long (and largely hidden) history, the scale of recent expansion and the unstable conditions in which growth has taken place, have served to challenge the hierarchies and disturb the boundaries separating further education and higher education.

In seeking out growth through collaboration with colleges, universities have been supported by a benevolent government policy regime that has encouraged higher level skills development to support an expanding knowledge economy, and funded unprecedented growth in higher education student numbers to bring this about. Many universities have taken full advantage of the opportunity to increase student numbers through successive additional student number bidding processes managed by the Higher Education Funding Council of England (eg HEFCE 1999). Guidelines for bidders consistently emphasised that collaborative bids with further education institutions were encouraged and welcomed, and later initiatives such as the Lifelong Learning Networks similarly supported collaboration between the sectors to widen access and enhance progression between FE and HE. It is easy to see how such a benign policy environment nurtures discourses of performativity when so many funding and quality benefits are associated with partnership projects. 
As recently as the beginning of the present decade Chowdry et al $(2010,4)$ were able accurately to write that 'There has been almost continually rising HE participation in the UK since the late 1960 s .... and, currently, $43 \%$ of 17 - to 30 -year-olds go to university. Further expansion to $50 \%$ participation is very likely, given that this is the government's target'. For a generation we have witnessed a steep increase in participation in both further and higher education. The social significance of this policy cannot be over-estimated, with funding 'targeted at levels below the bachelor degree with a new and shorter work-focused qualification (the foundation degree) introduced for near-universal levels of access and participation' (David et al, 2008, 6).

Through such policy manifestations it has been clear that HE led partnerships have been central to the working out of a higher education project consistent with the reformist and expansionist policy objectives of both major political parties, underpinned by the leading modernist principles espoused by the Robbins report (CHE 1963) and more recently the Dearing report (NCIHE 1997). These ideas, which have identified a central and privileged position for higher education, have formed the basis of a policy settlement across governments that has provided a remarkably secure and stable platform for universities to establish their authority as engines of the economy, their students cast as central contributors to seemingly unstoppable economic growth.

However this has changed. The May 2010 general election effected a change in government. The newly elected Conservative / Liberal Democrat coalition set a clear policy priority to reduce the national deficit (HM Government 2010), with both higher and further education cast as fair targets for funding reductions. Through the twin pillars of increased student tuition fees up to $£ 9,000$ per annum, and the mechanism of the student number control (the 'core and margin' policy, HEFCE 2011) that has put higher education student growth into reverse, the settlement that has characterized successive government policies (Ainley 1999) appears to be broken. Access to higher education is no longer seen as a right for an everincreasing proportion of the population. Employment based alternatives, in the form of apprenticeships, are being enthusiastically promoted (HMG 2011). Sharp divisions and instabilities are being driven into the sector occasioned by differential fees, a brake on growth in student numbers, and additional student number regulations which provide opportunities that encourage institutions to poach each others' students during the HE applications cycle, creating 'an untried, untested and unstable market for students' (Denham 2010).

\section{Falling participation}

At the time of writing, in the period leading up to the first intake of students paying increased fees, there are 10\% fewer England domiciled applicants in the UCAS applications system (UCAS 2012a), with some higher education institutions down more than a quarter on their equivalent position last year. Consequently, there are early indications of a dramatic and unprecented fall in the student population that comes under the Higher Education Funding Council for England's student number control arrangements, including the population with A- 
level grades of AAB or higher (THE 2012). As other major world economies are expanding higher education capacity to build a highly skilled workforce to meet the needs of their knowledge economies, and at a time of unprecedented participation and demand for university places in the UK, government has introduced the student number control system (BIS 2011) to limit growth in higher education, to 20,000 extra places in 2011/12 and just 5,000 extra for 2012/13. This rationing of higher education places is in danger of creating a balkanized post-compulsory education sector (Hargreaves 1994), in which competition for students dominates institutional strategy and partnerships are regarded as threat rather than opportunity - even though it has been clearly shown that even in a competitive market educational partnerships can be highly productive (Macbeth et al 1995).

The enduring impact of this changing landscape upon higher education partnerships remains to be seen, however we are witnessing a marked change in university / college relationships. Reviewing the position during the period of increasing participation summarised above, Parry et al $(2012,89)$ were able to comment that 'Generally relationships are good with little evidence of competitive behaviour (although at least two of the HEIs validating programmes in case-study colleges have recently either withdrawn from franchising or introduced greater restrictions, apparently to improve their own competitive positions)'. However during the last period a greater number of universities are tearing up their further education partnership agreements, bringing to an end collaborative provision that has characterized much of the growth in vocational higher education, including foundation degree development, over the last decade. For them, it is a matter of economics. In a time when student numbers are highly controlled, and institutional funding is contingent upon student fee income, it becomes necessary for an increasingly higher proportion of fee income to remain with the university rather than distributed to partners for teaching. Rule changes, such as the core and margin policy, that remove the stock-in-trade (student numbers), spell trouble for transactional partnerships.

\section{Structure vs agency}

Fresh leadership thinking is needed if universities and further education colleges are to work effectively and properly together in the interests of students. Partnerships that are strategic that generate shared values - are crucial to creating a post-compulsory sector that is joined up and aligned with core educational values, in which staff connect across institutional boundaries and students can progress from further into higher education.

Ball $(2003,215)$ has argued that closely related reform ideas are having a transformative and by implication unstoppable impact upon diverse education systems worldwide. This trend, which he terms an epidemic, 'appeals to politicians of diverse persuasions; and is becoming thoroughly embedded in the "assumptive worlds" of many academic educators'. His work on this chimes with that of other scholars who highlight reductionist perspectives and performativity in current educational discourse. Blackmore $(2004,439)$ described cultural 'dissonance' in education as a clash between 'performativity requirements based on 
efficiency and narrowly defined and predetermined criteria of effectiveness and success' and 'teachers' professional and personal commitment to making a difference for all students based on principles of equity'. As Pring (2007, 328), for example, suggests, we may not be aware of the impact that the dominant discourse has upon our thinking, however "it is language which shapes our consciousness" and which has led educationalists into uncritical acceptance of the trite, influenced by the "impoverished metaphors which govern our language and thought".

These arguments have been persuasive and influential in educational policy research. However there is a real danger that their analysis of restricted behaviours plays down the extent to which educational leaders have agency in their thinking and their practice, so that we take for granted that their 'assumptive world' (Ball, op cit) is necessarily locked into performativity and the crushing demands of the market and managerialism. This tension, between the duality of determinstic and voluntaristic models of action, has of course been a core concern of social science from Durkheim (1938 [1895] ) and Weber (1978 [1922] ) on. In our context it describes the extent to which educational leaders are viewed (by self and others) as subject to external rules and constraints or able to exercise professional decision and control. As Gleeson and James $(2007,452)$ put it, 'While the former denotes issues of structure (professionalism), in terms of how the professional is conditioned by material changes in working practices, the latter focuses on agency in the way professionals construct meaning and identity (professionality, e.g. through resistance, compliance, creative engagement) in the often paradoxical and contradictory conditions of their work'. It is essential to resist the easy assumption that education is epiphenomenal to polity and the economy. It is not. As Huberman $(1973,42)$ noted the "slow diffusion and low durability" of changes within the education system, so today we need to recognise that a deterministic account of the impact and penetration of education policy may well conceal the extent to which both institutional systems and human interventions huberman may divert policies from their intended consequences. As Elliott $(1993,39)$ has noted:

The implication that educational policy at the national level determines a particular pattern or mode of decision making throughout an institution should be resisted. To do so will involve managers, researchers, and others who wish to know, seeking out different understandings and differing practices within educational institutions.

In short, the iron glove of policy determinism should not be allowed to stay the hand of educational leaders who inform and influence policy, and the process by which they make considered responses to political, cultural and technological change and devise considered strategies to contain or exploit both intended and unintended consequences.

\section{Leading change}

One of the four core capacities for building greater change capacity identified by Fullan $(1993,21)$ is collaboration, the others being: personal vision-building, inquiry and mastery. 
It is vital, if educational institutions are to realise their proper strategic connection with the arts, culture, scholarship and the broader humanity, that educational leaders resist narrow instrumentalism or technical performativity and feel empowered to act thoughtfully, become aspirational, engage globally and enact transformational strategies. In particular, educational leaders who can embody reflective practice in their work will be able to engage successfully with other leaders across the post compulsory sector and elsewhere through a shared community of educational practice. As Jameson $(2008,21)$ has pointed out, this requires 'the conscious adoption of values-based distributed and collaborative forms of team leadership to develop trust and enable genuine dialogue between professional leaders in post-compulsory education'.

Much of the theoretical literature on educational partnerships has a predominant concern with how to establish and sustain successful partnerships (see eg Thomas et al 2002). Within this, the active support of senior managers is invariably identified as a key requirement. However active support is a necessary but not sufficient condition of successful educational partnership. 'While change must be well managed - it must be planned, organised, directed and controlled - it also requires effective leadership to introduce change successfully: it is leadership that makes the difference' (Gill 2003, 307).

Michael Fullan $(1991,1998)$ has for many years led thinking on the issues educational leaders face in managing multiple changes in their institutions.. He graphically describes the contemporary educational climate for schools in which policy changes seem continuous and continually pressing when he observes that 'Out there' is now 'in here' as government policy, parent and community demands, corporate interests, and ubiquitous technology have all stormed the walls of the school (Fullan 1998, 1). In reviewing the poor performance of management theory in improving business and educational organisations, Fullan (ibid, 2) concludes that in light of the complexity of each organisation's unique personalities and cultural conditions there is no silver bullet, and suggests:

Instead of hoping that the latest technique will at last provide the answer, we approach the situation differently. Leaders for change get involved as learners in real reform situations. They craft their own theories of change, consistently testing them against new situations. They become critical consumers of management theories, able to sort out promising ideas from empty ones. They become less vulnerable to and less dependent on external answers. They stop looking for solutions in the wrong places.

Wheatley $(1994,7)$ brings a similar perspective to her work on leadership, arguing that no organisation 'can be changed by imposing a model developed elsewhere' and that 'there is no objective reality out there waiting to reveal its secrets'. These scholars' insightful contribution to our thinking on leading educational change is to pull our gaze away from seductive management theories as if they can be transplanted straightforwardly into universities, colleges and schools. They remind us that leaders must lead, and that in order to do it well, they must imagine, innovate, think out of the box. Interestingly for our current 
discussion of educational partnerships, Fullan $(1998,3)$ exhorts educational leaders to "move toward the danger" in forming new alliances. By 'the danger' he is referring to the pervasive influence of volatile policy shifts and other external forces such as competitor institutions on schools. He argues that since the external environment permeates the fabric of the school, external engagement is essential, and that "Successful schools are not only collaborative internally, but they also have the confidence, capacity, and political wisdom to reach out, constantly forming new alliances." (ibid.)

Writing in the context of collaborative leadership and communities of practice within post compulsory education institutions, Jameson $(2008,22)$ maintains 'If undertaken genuinely and effectively, collaborative leadership will tend to transform organisations to become more inclusive places through synergistic, dynamic processes of active engagement in leadership's vision and values, while being empowered with the knowledge, authority, responsibility and goal-directed problem-solving to improve provision'. This is a principle of collaborative leadership that can be usefully generalised to partnerships between institutions since the model embodies an ethical focus upon students and educational improvement. In an interesting discussion of 'chaotic reflexivity', Helen Gunter $(1997,92)$ introduces the notion of the 'bounded instability' of educational organisations, emphasising the nonlinearity and complexity of educational systems, consistent with the metaphors of 'loosely coupled systems' (Weick 1988) and 'garbage can' decision making within organised anarchies (Cohen and March 1989). Gunter (ibid) rightly suggests that these insights about the relatively fluid nature of educational organisations warn against 'ring binder management' and lead us to policy-literate reflective practice, in particular 'considering how disorder can lead to a positive process of creative self-renewal'. This way of thinking about educational leadership points away from insular problem-fixing approaches, and towards creative energy, professional dialogue and partnership

\section{Education and values}

In order to resist policy directions that limit scope and capacity in higher education, in the face of seemingly overwhelming turbulence in education, now more than ever, it is necessary to direct our attention to the fundamental purposes of education and remember that education has at its core a moral purpose - to make a difference, to bring about improvements, and that therefore effective leadership practice is rooted in values - a practice that has been rightly described as a 'moral art' (Hodgkinson 1991). In persuading educators and those who lead them to think and act ethically in responding to policy directions, we can do no better than recall the advice of G.H Bantock $(1965,120)$, writing nearly half a century ago:

Because, as a matter of fact, certain changes take place in the social structure, the educator is not morally obliged to follow them unless he is persuaded, on grounds other than the fact of change, that these changes are for the good. The ethical proposition that all change is necessarily change in the direction of the good, is not one that human experience could in any way sustain. 
The lessons for today are that if policy directions, such as limiting wider participation in higher education and reducing rather than increasing participation, are anti-educational then university leaders can and should resist them. Effective university leadership should be critical, questioning received wisdom and challenging accepted practice. Critique should characterise analysis of all strategic options, even to the extent of questioning particular forms of educational organisation. It is interesting that in the current economic crisis, whilst deficit reduction is the coalition government's mantra, the impact of policies to achieve this on educational institutions seems to be ignored or even unnoticed. Yet the fact is that the prescriptive and misguided economic theory that seeks to achieve national economic health through budget reduction alone is being replicated in many further and higher educational institutions. As Biggs (2005) has noted in the case of further education colleges, when organisations face financial or other crisis, transactional leadership appears to offer a more effective form of crisis management, and greater oprganisational security. So we are seeing numerous instances of large scale staff redundancy programmes, course closures, outsourcing of core services, and reduction in the amount and range of educational provision. It should be clear - but seems not to be to those who lead such institutions - that such measures, though possibly effective in the short term to avoid an end of year deficit, will over the longer term undermine the culture, health and prospects of the organisation. Invariably dramatic and draconian cutbacks are the outcome of a failure to read the environment effectively, to maximise the staff resource, and to build capacity - especially in a harsh funding environment. Above all, they are a failure of morality, vision and imagination.

Joint working where each partner brings distinctive strengths can be a powerful way of gaining control over the uncertainties of a competitive educational market (Glatter 1995, McPherson et al 1986, Pfeffer and Salancik 1978). Educational leaders who wish to be outstanding must seek transformational partnerships, since it is these that will lead an organisation to new levels of achievement and aspiration. It is sheer folly for university executives to sever their progression links at a time when, more than ever, universities need to extend progression routes from local and regional colleges into their institutions.

Purposeful strategic collaboration of this kind can establish and sustain a raft of certainty in an unpredictable education policy climate.

Transformative partnerships are rooted in educational values and are therefore worthwhile and sustainable. Performative partnerships are transactional and will often not persist beyond the narrow compass of the exchange they were set up to achieve. They certainly have little to do with morality - as Ball $(2006,11)$ has commented, "Ethical reflection is rendered obsolete in the process for goal attainment, performance improvement and budget maximisations .... Value replaces values, except where it can be shown that values add value". There is a danger that the assumptive model of such analysis can generate a discourse of negativity and pessimism and paralyse the will to take on the leadership of educational change. This analysis should not, however, determine how a leader acts, rather it should prompt actions that are truly educational, rooted in morality, and that have clear attachment to identifiable educational values. The rethinking that is needed is akin to venturing into 'the land of the other' as called for by Lumby $(2006,164)$ in her review of diversity and leadership in post 
compulsory education, and in so doing 'to contribute to equity in a diverse society, reflecting both moral and economic imperatives, right and good'. Thinking about partnerships in this way is certainly not fashionable, however it offers, for university leadership, a powerful, viable and desirable route to both transformational educational practice and institutional resilience. 


\section{References}

Ainley. P. (1999), Learning Policy: Towards the Certified Society, New York, St Martin's Press

Avis, J. and Bathmaker, A-M. (2004) Critical Pedagogy, Performativity and a Politics of Hope: trainee further education lecturer practice, Research in Post-Compulsory Education, 9, 2, 301-313

Ball, S. (2003) The teacher's soul and the terrors of performativity, Journal of Education Policy, 18, 2, 215-228

Ball, S. (2006) Education policy and social class: the selected works of Stephen J. Ball (London, Routledge).

Bantock, G (1965) Education and Values, London, Faber and Faber

Biggs, A (2005) Middle Managers in English Further Education Colleges

Understanding and Modelling the Role, Educational Management Administration Leadership $33,127-50$

Blackmore, J. (1994) Leading as emotional management work in high risk times: the counterintuitive impulses of performativity and passion, School Leadership and Management, 24, 4, 439-459

Chowdry, H., Crawford, C., Deardon, L., Goodman, A, and Vignoles, A. (2010) Widening Participation in Higher Education: Analysis Using Linked Administrative Data, Forschungsinstitut zur Zukunft der Arbeit / Institute for the Study of Labor, Discussion Paper no. 4991, IZA, Bonn, Germany.

Committee on Higher Education (1963), Higher education: report of the Committee appointed by the Prime Minister under the Chairmanship of Lord Robbins 1961-63 (The Robbins Report), Cmnd. 2154, London: HMSO

David, M. et al (2008) Widening participation in higher education: A Commentary by the Teaching and Learning Research Programme http://www.tlrp.org/pub/documents/HEcomm.pdf accessed on $17^{\text {th }}$ July 2012.

Denham, J. (2010) speaking in House of Commons debate on Higher Education Fees, $9^{\text {th }}$ December 2012, available at http://www.publications.parliament.uk/pa/cm201011/cmhansrd/cm101209/debtext/1012 09-0002.htm accessed 17th July 2012

Department for Business, Innovation and Skills (2009) Higher ambitions: The future of universities in a knowledge economy. http://www.bis.gov.uk/policies/highereducation/shape-and-structure/higher-ambitions, accessed $15^{\text {th }}$ July 2012 
Department for Business, Innovation and Skills (2011) Higher Education: Students at the heart of the system http://www.bis.gov.uk/assets/biscore/higher-education/docs/h/11-944higher-education-students-at-heart-of-system.pdf , accessed 15th July 2012

Durkheim, E. (1938 [1895] ) The Rules of Sociologoical Method, New York, Free Press.

Elliott (1993) Whose Quality is it Anyway?: assumptions underlying quality models in further education, Quality Assurance in Education 1 (1) 34-40

Fullan, M. (1991) The New Meaning of Educational Change, London, Cassell.

Fullan, M (1993) Why teachers much become change agents, Educational Leadership, 50, 6, para 2, http://www.michaelfullan.ca/Articles_98-99/03_93.htm accessed 1st July 2012

Fullan, M. (1998) Leadership for the 21st Century: Breaking the Bonds of Dependency, Educational Leadership, 55, 7, pp. 1-6

Gill, R. (2003) Change management - or change leadership? Journal of Change Management, 3, 4, 307-18

Glatter, R (1995) 'Partnership in the market model: is it dying?' in Macbeth, A., McCreath, D., and Aithinson, J. (Eds.) Collaborate or Compete? Educational partnerships in a market economy, London, The Falmer Press.

Gleeson D. and James, D. (2007): The paradox of professionalism in English Further Education: a TLC project perspective, Educational Review, 59:4, 451-467

Hargreaves, A. (1994) Changing Teachers, Changing Times, London, Cassell

HEFCE (1999) Additional student places and funds: Invitation to bid, 99/56, Bristol, HEFCE.

HEFCE (2011) Student number controls for 2012-13 - Invitation to bid for student places, 2011/30, Bristol, HEFCE.

HM Government (2010) The Coalition: our programme for government, Cabinet Office, http://www.direct.gov.uk/prod_consum_dg/groups/dg_digitalassets/@dg/@en/documen ts/digitalasset/dg_187876.pdf accessed 1st July 2012

HM Government (2011) Plan for Growth, Treasury / BIS, http://cdn.hmtreasury.gov.uk/2011budget_growth.pdf accessed 1st July 2012

Hodgkinson, C (1991) Educational Leadership: The Moral Art, New York, SUNY Press Huberman, A. (1973) Understanding Change in Education: An introduction, Paris, UNESCO Jameson (2008) Professional communities of leadership practice in post-compulsory education, Bristol, Escalate Discussions in Education Series, available at: 
http://gala.gre.ac.uk/2890/1/Jameson_ESCALATE_Leadership_2008.pdf accessed 12 June 2012

Lumby, J. (2006) Conceptualizing Diversity and Leadership, Educational Management Administration \& Leadership, 34, 2, pp. $151-165$

Macbeth, A., McCreath, D., and Aithinson, J. (Eds.) (1995) Collaborate or Compete? Educational partnerships in a market economy, London, The Falmer Press.

McPherson, R., Crowson, R and Pitner, N (1986) Managing Uncertainty: Administrative theory and practice in education, Columbus, Ohio, Charles Merrill

Morgan, J (2012) Wave of private subsidiaries tests the barriers of regulation, Times Higher, 6 September 2012, p.9

Mulcahy, D. (2004) Making Managers within Post Compulsory Education: policy, performativity and practice, Research in Post-Compulsory Education, 9, 2, 183-202.

National Committee of Inquiry into Higher Education (1997) Higher Education in the Learning Society,(The Dearing Report) https://bei.leeds.ac.uk/Partners/NCIHE/ accessed $7^{\text {th }}$ July 2012

Parry, G. (2008) HE Patterns of Participation in England, Higher Education Quarterly, 51(1) pp. 6-28.

Parry, G., Callender, C., Scott, P. and Temple, P (2012) Understanding higher education in further education institutions, London, HMSO, Department for Business, Innovation

Pfeffer, J., and Salancek, G. (1978) The External Control of Organisations, New York, Harper and Row.

Pring, R. (2007) Reclaiming philosophy for educational research Educational Review, 59(3), 315-330.

Thomas, L., Cooper, M. and Quinn, J. (Eds.) (2002) Collaboration to Widen Participation in Higher Education, Stoke on Trent: Trentham Books.

Times Higher Education, Figures reveal huge drop in students starting university, 14 September, http://www.timeshighereducation.co.uk/story.asp?storycode=421152 Accessed $20^{\text {th }}$ September 2012

Trow, M. (1974), 'Problems in the transition from elite to mass higher education' in OECD Policies for Higher Education (Paris, Organisation for Economic Cooperation and Development).

UCAS (2012a) Media release, $9^{\text {th }}$ July, Data reported for applications considered on time for 30 June deadline, 
http://www.ucas.com/about_us/media_enquiries/media_releases/2012/20120709 accessed 18th July 2012.

Weber, M. (1978 [1922] ) Economy and Sopciety, Berkeley, University of California Press.

Wheatley, M. (1994) Leadership and the New Science, San Francisco, Berrett-Koehler Publications Inc.

Wood, C. (2012) Exploring the retention of students studying higher education at partner colleges, Research in Post-Compulsory Education 17, 1, 21-37 